\title{
Dietary substitution of maize with processed cocoyam (Xanthosomasagittifolium) as energy source for finisher broilers production
}

Onunkwo, D. N., Anyaegbu, B. C., Adedokun, O. O. and Bassey, E. G.

College of Animal Science and Animal Production,

Michael Okpara University of Agriculture, Umudike, Abia State, Nigeria

Corresponding Author's E-mail: donunkwo1@gmail.com, 08033388622

\section{Abstract}

Energy feed source like maize is expensive contributing about 50-55\% of the cost of poultry and pig diets. Thus, the study was carried out to determine the dietary substitution of maize with soaked cocoyam Xanthosoma sagittifolum as energy source for finisher broiler production. The soaked cocoyam tuber meal was used to replace yellow maize in the diets of finisher broilers. Xanthosoma cocoyam corms were harvested, cleaned of soil and chopped into bits of about $0.2 \mathrm{~cm}$. The chopped tannia was soaked in water in a large vat for 24 hours to reduce the ant nutrients and later on separated from the water and dried with microwave oven. The dried cocoyam was milled and then used. The proximate chemical composition showed that soaked cocoyam tuber meal contained $8.05 \%$ moisture, $91.95 \%$ dry matter, $10.08 \%$ ash, $2.01 \%$ crude protein, $1.60 \%$ ether extract, 3.80\% crude fibre, $74.46 \% \mathrm{NFE}$ and $3158.92 \mathrm{Kcal} / \mathrm{kg}$ DM metabolizable energy. In the finisher broiler trial, the control diet contained maize as the main energy source while diets 2,3,4 and 5contained 15\%, 20\%, 25\%, and 30\% soaked cocoyam tuber meal finisher diet was fed to a group of 30 broiler chicks for 4 weeks using completely randomized design. Each treatment was further grouped into 3 replicated of 10 birds each. The broilers were kept in deep litter and given feed and water ad libitum. Parameters measured included: initial body weight, find body weight, body weight gain, feed intake, feed conversion ratio, cost of production and carcass characteristic. In the finisher feeding trial, the finisher broilers on the control diet, diet $5(30 \%$ SCYM), and diet 3 $(20 \%$ SCYM) recorded similar feed intake which were significantly different $(P<0.05)$ from those on the other diets. In terms of body weight gain, the finisher broilers on $20 \%$ soaked cocoyam tuber meal diet recorded significantly $(P<0.05)$ high body weight than those on other diets while the finisher broilers on 25\% soaked cocoyam tuber meal recorded the poorest body weight gain. It appeared that, the finisher broilers could not tolerate high levels of soaked cocoyam tuber meal in their diets. Cost of production (cost offeed $x$ feed conversion ratio) was lowest for diet 5 (30\% SCYM) N375 versus N422.99 for control diet in the finisher trial. The internal organs expressed as percent of the live weight were not affected by the treatments. The finisher broilers on diet 3 recorded the highest dressing out percentage of 73.90.There were no significant difference $(p<0.05)$ on percentage wings and back cut of the finisher broiler group in all the diets. The finisher broilers on diet 4 (25\% SCYM) yielded the highest percent breast muscle of $32.4 \%$ followed by those on 15\% SCYM (diet 2) and 20 SCYM (diet 3). The finisher broilers on the control diet yielded the highest percent thigh of $18.3 \%$ and the poorest were those on diet 2(15\% SCYM). The results of the trial have shown that soaked cocoyam tuber meal can be used to substitute maize at 20\% in the diets of finisher broilers without affecting the weight gain, feed intake and feed conversion ratios as indicated in this study.

Keywords: Dietary, substitution, maize, processed, cocoyam, energy source, finisher broilers, performance 


\section{Dietary substitution of maize with processed cocoyam (Xanthosomasagittifolium)}

\section{Introduction}

Energy feed sources like maize is expensive contributing about $50-55 \%$ of the cost of poultry and pig diets. The production of maize is low which means, it does not meet its demand (Agbede et al., 2008; Hamza et al., 2003; Okereke et al., 2006). The cost of feed has invariably raised the cost of animal production and hence the selling price of animal products such as eggs, pork, and meat. This has worsened the low animal intake of Nigerians. Every adult or grown up person should consume a minimum of $35 \mathrm{~g}$ of animal protein daily (FAO, 1982). The average in West Africa presently is only 7g (Oluyemi, 1978). Adejinmi et al., 2000 reported the rising cost of feed resources in livestock production have been established as a serious impediment to meeting the demand for animal protein particularly in developing countries. The high cost of feed can be reduced by compounding of feed in a way that all the required nutrients come from cheap alternative energy and protein sources (Onyimonyi and Okeke, 2005).

One possible source of cheap energy is the cocoyam (Xanthosoma sagitifolium), which possesses readily available energy with easily digestible carbohydrate. The cocoyam has been described as possessing nutritional quality which could compare favourably with cassava, potatoes and yam (Bello, 1976).

The starch content is 17 to 34.5 percent, the average approximate composition of the edible portion has been quoted as: energy $566 \mathrm{kj} / 100 \mathrm{~g}$; water $70-77$ percent; protein 1.3-3.7 percent; fat $0.2-0.4 \%$, carbohydrate $17-20 \%$, fibre $0.6-1.9 \%$, ash $0.6-1.3 \%$, calcium $20 \mathrm{mg} / 100 \mathrm{~g}$; Iron $1 \mathrm{mg} / 100 \mathrm{~g}$; ascorbic acid 6-10mg/100g (Gooding, 1978). In Puerto Rico, production appears to exceed 20,000t/a and in Dominica Republic, 30,000t/a Gooding (1987). About $10 \mathrm{~kg}$ cocoyam (Xanthosoma spp) yields $3 \mathrm{~kg}$ of flour (Gooding 1978). According to Anyaegbu et al. (2016), the NFE of fresh Xanthosoma sagitifolium was $63.91 \%$ and dried cocoyam, $74.40 \%$ while crude protein and metabolizable energy were $3.94 \%$ and $3179 \mathrm{kcal} / \mathrm{kg}$ DM respectively. However, its use in the feeding of monogastric animals could be encumbered by the presence of some antinutritionalfactors like Oxalate, tannins, trypsin inhibitors, saponins and cyanide which adversely affect protein and energy utilization in monogastric nutrition (Onu et al., 2004). Cooking and or supplementation with oil are common acceptable means of detoxification among Nigerians.

Considering the various attributes of Xanthosoma sagittifolium, it would appear that appropriate utilization of this feed stuff can be used to replace maize to produce low cost diets that can be efficient in promoting performance of finisher broilers and reduce demand pressure on maize as well as cost of production.

\section{Materials and methods Experimental site}

The experiment was carried out at the poultry unit of the Teaching and Research Farm of Michael Okpara University of Agriculture, Umudike, Abia State, Nigeria. The area is located on latitude $5^{0} 27^{1}$ North, longitude $7^{0} 32^{1}$ East, in the rain forest zone in Umuahia, Abia State of Nigeria. This site has a mean daily temperature of between $27^{\circ} \mathrm{C}-36^{\circ} \mathrm{C}$ and a minimum of $20^{\circ} \mathrm{C}-26^{\circ} \mathrm{C}$ with relative humidity between 57 and $91 \%$ and annual rainfall of $200 \mathrm{~mm}$ per annum and an altitude of $122 \mathrm{~m}$ above sea level. It is therefore, a humid tropical environment with temperature and relative humidity that are significant in agriculture production (Eburuja, 2010).

Procurement and processing of feed ingredients 
Tannia cocoyam corm (Xanthosoma sagittifolium) was obtained from Ikot Ekpene L.G.A, in Akwa-Ibom State. The corms were harvested, cleaned of soils and chopped into bits of about $0.2 \mathrm{~cm}$. Chopped Tannia cocoyam were soaked in water for about 24 hours to reduce the anti-nutrients and later on separated from the water and dried with Microwave oven. The dried cocoyam were milled and then stored. Other ingredients like maize, palm kernel cake, fish meal, blood meal, bone meal, vitamins premix, salt, etc. were procured from Jocan Agro Services Umuahia, Abia State.

\section{Chemical analysis offeed ingredients}

The processed feed ingredients; Tannia cocoyam, palm kernel cake, brewers dried grains, blood meal, fish meal, were subjected to proximate analysis according to AOAC (1995) to determine their nutrient composition and gross energy.. The components that were determined included dry matter (DM), Crude Protein (CP), Ether Extract (EE), and Nitrogen free Extract (NFE).

\section{Experimental design}

The design of the study was Completely Randomized Design (CRD).

The Statistical Model is;

$\mathrm{Yij}=+\mathrm{Ti}+\mathrm{eij}$

Where;

Yij= Individual observation

$=$ Population mean

$\mathrm{Ti}=$ Treatment effect

eij $=$ Error effect

\section{Anti-nutrients determination}

The test materials; fresh and soaked cocoyam (Xanthosoma sagittifolium) were analyzed for the anti-nutrients content such as oxalate, phytic acid, saponins, tannins and cyanide.

\section{Experimental finisher broilers diets}

For the finishers broilers, a control diet (diet 1) containing maize as the major source of energy were also made such that diets 2, 3, 4 and 5 contained $15 \%, 20 \%, 25 \%$ and $30 \%$ of soaked cocoyam meal supplemented with palm oil to replace maize in the diets. Other dietary ingredients were varied in order to provide the required protein and energy for the broilers. The following diets were produced and tested in the feed trial.

Table 1: Ingredient and Nutrient Composition of the Experimental Finisher Broiler Diets

\begin{tabular}{llllll}
\hline Ingredients \% & $\begin{array}{l}\text { Diet 1 } \\
\text { control }\end{array}$ & $\begin{array}{l}\text { Diet 2 15\% } \\
\text { SCYM }\end{array}$ & $\begin{array}{l}\text { Diet 3 20\% } \\
\text { SCYM }\end{array}$ & $\begin{array}{l}\text { Diet 4 25\% } \\
\text { SCYM }\end{array}$ & $\begin{array}{l}\text { Diet 5 30\% } \\
\text { SYCM }\end{array}$ \\
\hline Maize & 60.00 & 51.00 & 48.00 & 45.00 & 42.00 \\
SCYM $^{*}$ & - & 9.00 & 12.00 & 15.00 & 18.00 \\
Soyabean meal & 18.00 & 16.40 & 16.40 & 16.40 & 16.40 \\
PKC & 5.60 & 5.60 & 5.60 & 5.60 & 5.60 \\
BDG & 6.10 & 6.10 & 6.10 & 6.10 & 6.10 \\
Blood med & 3.00 & 3.00 & 3.00 & 3.00 & 3.00 \\
Bone meal & 3.70 & 3.70 & 3.70 & 3.70 & 3.70 \\
Vitamin/mineral & & & & & \\
Premix** & 0.25 & 0.25 & 0.25 & 0.25 & 0.25 \\
Palm oil & - & 1.60 & 1.60 & 1.60 & 1.60 \\
l-methionine & 0.10 & 0.10 & 0.10 & 0.10 & 0.10 \\
Common salt & 0.25 & 0.25 & 0.25 & 0.25 & 0.25 \\
\hline Total & 100.00 & 100.00 & 100.00 & 100.00 & 100.00 \\
\hline
\end{tabular}

Calculated Nutrient Composition of the Experimental Finisher Broiler Diets

\begin{tabular}{llllll} 
Crude protein (\%) & 20.62 & 19.38 & 19.19 & 19.00 & 18.81 \\
Crude fibre (\%) & 4.64 & 4.60 & 5.05 & 5.05 & 5.05 \\
Ether extract (\%) & 6.24 & 6.16 & 5.86 & 5.87 & 5.75 \\
Ash (\%) & 2.03 & 3.00 & 3.02 & 3.02 & 2.99 \\
Calcium (\%) & 1.75 & 1.74 & 1.77 & 1.741 .74 & 1.72 \\
Phosphorus (\%) & 1.38 & 1.37 & 1.81 & 1.81 & 1.80 \\
M.E.kal/kg & 2875.64 & 2952.00 & 2942.20 & 2932.00 & 2921.81 \\
\hline PKC: Palm kernel cake, BDG: & Brewers' Dried Grain , *soaked cocoyam meal, **to provide per kg diet: see \\
starter uf/remix &
\end{tabular}




\section{Dietary substitution of maize with processed cocoyam (Xanthosomasagittifolium)}

Management of the experimental finisher broiler chicks

A four week feeding trial was conducted using unsexed 150 Anak finisher broiler chicks (Fidanbroiler Chicks) at four weeks of age. They were divided into five groups of 30 broilers e ach and each treatment was subdivided into three replicates of 10 broilers each. Each replicate was housed in a pen. The broilers were weighed individually at the beginning of the experiment and their average initial weight and sex balanced and weighed weekly thereafter for determination of their growth performance. The broilers were assigned the experimental diets using completely randomized design for four weeks. Both water and feed were given ad libitum.

\section{Carcass evaluation}

At the end of the feeding trial, two birds from each treatment were randomly selected, starved of feed but not water for 24 hours and then weighed and slaughtered for the determination of the following internal organ weights (heart, liver, kidney, spleen, lungs), cut part weight (thigh muscle, wings, backcut, drumstick and breast muscle), abdominal fat weight and dressed weight. The internal organs weights were expressed as percentage of the live weight.

Table 4: Proximate composition of Experimental Finisher Broilers Diets containing different level of processed cocoyam tuber meal

\begin{tabular}{lllllll} 
Parameters & $\begin{array}{l}\text { Diet 1 } \\
\text { control }\end{array}$ & $\begin{array}{l}\text { Diet 2 } \\
\mathbf{1 5 \%} \text { SCYM }\end{array}$ & $\begin{array}{l}\text { Diet 3 } \\
\mathbf{2 0 \%} \text { SCYM }\end{array}$ & $\begin{array}{l}\text { Diet 4 } \\
\mathbf{2 5 \%} \text { SCYM }\end{array}$ & $\begin{array}{l}\text { Diet } \\
\mathbf{5 3 0} \% \\
\text { SYCM }\end{array}$ & SEM \\
\hline Dry matter (\%) & 89.70 & 89.86 & 89.88 & 89.76 & 89.81 & 0.03 \\
Moisture (\%) & 10.29 & 10.14 & 10.12 & 10.24 & 10.91 & 0.03 \\
Ash (\%) & 7.91 & 11.26 & 13.20 & 11.77 & 7.79 & 0.97 \\
CP (\%) & 20.40 & 19.45 & 19.66 & 20.30 & 20.85 & 0.57 \\
EE (\%) & 3.65 & 5.30 & 3.85 & 2.70 & 4.45 & 0.39 \\
CF (\%) & 8.15 & 8.60 & 6.40 & 6.50 & 6.60 & 0.67 \\
NFE (\%) & 48.32 & 45.25 & 47.77 & 44.49 & 50.12 & 0.92 \\
\hline CP: Crude fibre, EE: & \multicolumn{2}{c}{ Ether extract, CF: } & Crude fiber, NFE: & Nitrogen free extract
\end{tabular}

Table 5: Performance of the Experimental Finisher Broilers FedCocoyam Diets

\begin{tabular}{lllllll}
\hline Parameters & $\begin{array}{l}\text { Diet 1 } \\
\text { Control }\end{array}$ & $\begin{array}{l}\text { Diet 2 } \\
\mathbf{1 5 \%}\end{array}$ & $\begin{array}{l}\text { Diet 3 } \\
\mathbf{2 0 \%}\end{array}$ & $\begin{array}{l}\text { Diet 4 } \\
\mathbf{2 5 \%}\end{array}$ & $\begin{array}{l}\text { Diet 5 } \\
\mathbf{3 0 \%}\end{array}$ & SEM \\
& & SCYM & SCYM & SCYM & SCYM & \\
\hline Initial body wt (kg) & $1.19^{\mathrm{a}}$ & $1.03^{\mathrm{b}}$ & $1.04^{\mathrm{c}}$ & $1.04^{\mathrm{c}}$ & $1.22^{\mathrm{a}}$ & 0.04 \\
Final body wt (kg) & $2.33^{\mathrm{ab}}$ & $2.04^{\mathrm{b}}$ & $2.31^{\mathrm{c}}$ & $1.95^{\mathrm{c}}$ & $2.27^{\mathrm{ab}}$ & 0.06 \\
Body wt. gain (kg) & $1.14^{\mathrm{ab}}$ & $1.01^{\mathrm{b}}$ & $1.27^{\mathrm{a}}$ & $0.91^{\mathrm{c}}$ & $1.05^{\mathrm{b}}$ & 0.06 \\
Daily body wt gain (g) & 40.71 & 36.07 & 45.36 & 32.50 & 37.50 & 1.94 \\
Daily feed intake (g) & $139.12^{\mathrm{a}}$ & $129.17^{\mathrm{b}}$ & $134.17^{\mathrm{a}}$ & $132.50^{\mathrm{b}}$ & $136.67^{\mathrm{a}}$ & 5.22 \\
Feed conversion ratio & $3.41^{\mathrm{ab}}$ & $3.58^{\mathrm{ab}}$ & $2.96^{\mathrm{a}}$ & $4.08^{\mathrm{b}}$ & $136.67^{\mathrm{a}}$ & 0.16 \\
Mortality & - & - & - & - & - & - \\
\hline abc & & - & & - &
\end{tabular}

${ }^{\mathrm{abc}}$ means within the same row with different superscripts are significantly different $(\mathrm{P}<0.05)$

\section{Body weight gain}

In the finisher feeding trial, the broilers on $20 \%$ soaked cocoyam tuber meal (SCYM) recorded the highest body weight gain of $1.27 \mathrm{~kg}$ which was significant higher $(\mathrm{P}<0.05)$ than those on the control diet. The finisher broilers group on 25\% SCYM recorded the poorest body weight gain. This could be due to the high level of soaked cocoyam tuber meal in their diets.

In the finisher phase (Table 5) the feed conversion ratio of the group on $20 \%$ soaked 
cocoyam tuber meal based diet was significantly superior $(\mathrm{P}<0.05)$ to other groups. The group on $25 \% \mathrm{SCYM}$ recorded the poorest feed conversion ratio.

\section{Percentage dressed weight}

The finisher broiler on 20\% SCYM (diet 3) recorded significantly $(\mathrm{P}<0.05)$ the highest dressing out percentage of 73.90 following by those on the control diet, 15\% SCYM (diet 2$)$, diet $5(30 \% \mathrm{SCYM})$ and $\operatorname{diet} 4(25 \%$ SCYM) respectively.

Economics of production of experimental finisher broilers

In the finisher broiler trial, the cost of production of $1 \mathrm{~kg}$ of cocoyam based finisher broiler diet was cheapest for diet 5 (A109.65) and the costliest was the control $\operatorname{diet}(\$ 121.55)$.

Table 7: Economics of Finisher Broilers Fed Experimental Diets

\begin{tabular}{|c|c|c|c|c|c|c|}
\hline Parameters & $\begin{array}{l}\text { Diet } 1 \\
\text { Control }\end{array}$ & $\begin{array}{l}\text { Diet } 2 \\
15 \% \\
\text { SCYM }\end{array}$ & $\begin{array}{l}\text { Diet } 3 \\
20 \% \\
\text { SCYM }\end{array}$ & $\begin{array}{l}\text { Diet } \\
25 \% \text { SCYM }\end{array}$ & $\begin{array}{l}\text { Diet5 } \\
30 \% \\
\text { SCYM }\end{array}$ & SEM \\
\hline Cost/kg feed ( & $121.55^{\mathrm{c}}$ & $116.53^{b}$ & $113.73^{b}$ & $111.73^{\mathrm{ab}}$ & $109.65^{\mathrm{a}}$ & 1.84 \\
\hline Cost of prod./bird ( & $422.99^{c}$ & $376.39^{\mathrm{b}}$ & $305.06^{\mathrm{b}}$ & $493.85^{\mathrm{ab}}$ & $375.00^{\mathrm{a}}$ & 27.80 \\
\hline
\end{tabular}

abc means within the same row with different superscripts are significantly different $(\mathrm{P}<0.05)$

\section{Discussion}

Anti-nutrient content and proximate composition of cocoyam (Xanthosoma sagittifolium)

The result of the trials in respect to the antinutrients content of both fresh and soaked cocoyam tuber reaffirmed the earlier work of Ahamefule and Odemelan (2008) that 24 hours soaking duration produced better results and would be preferred for reducing tannin and cyanide in feed ingredients. The acridity factors due to the presence of oxalate are reduced by peeling, grading, soaking and fermentation operation during processing (FAO, 1990). It therefore follows that diets based on soaked cocoyam tubers as source of energy could contain very little trace of Cyanide, tannins, oxalate, saponnins and phytic acid.

Performance of finisher broilers fedprocessed cocoyam based diets

The response of the finisher broilers to the soaked cocoyam tuber meal based diets was quite different in terms of feed intake, body weight gain and feed conversion ratio.
The finisher broilers on the control diet $(30 \%$ SCYM) and diet 3 (20\% SCYM) recorded similar feed intake from those on other diets. In terms of body weight gain, the finisher broilers on $20 \%$ soaked cocoyam tuber meal recorded higher body weight gain of $1.27 \mathrm{~kg}$ than those on the control diet. The finisher broilers on $25 \%$ soaked cocoyam tuber meal recorded the poorest body weight gain. It appeared that the finisher broilers could not tolerate high levels of soaked cocoyam tuber meal in their diets. In terms of cost of production, diet $5(30 \%$ SCYM) was the most efficient, giving a cost of N375.00 versus (N422)for the control diet. Possibly, the finisher broilers could not tolerate high level of soaked cocoyam tuber meal based diets due to the remaining anti nutrients in the soaked cocoyam such as tannins, oxalates, cyanide, phytic acid and saponins which according to Onu et al. (2004) which adversely affected protein and energy utilization in broilers.

The percentage cut part weight of the experimental finisher broilers are shown in (table 6). 


\section{Dietary substitution of maize with processed cocoyam (Xanthosomasagittifolium)}

Table 6: Percentage Cut Part weights of the Experimental Finisher Broilers

\begin{tabular}{lllllll}
\hline Parameters & Diet 1 & Diet 2 & Diet 3 & Diet & Diet 5 & SEM \\
\hline \% High & $18.31^{\mathrm{a}}$ & $17.36^{\mathrm{ab}}$ & $16.67^{\mathrm{b}}$ & $17.83^{\mathrm{ab}}$ & $17.66^{\mathrm{ab}}$ & 0.20 \\
\% Drumstick & $15.01^{\mathrm{ab}}$ & $14.10^{\mathrm{b}}$ & $14.75^{\mathrm{b}}$ & $16.12^{\mathrm{a}}$ & $13.59^{\mathrm{c}}$ & 0.38 \\
\% Breast muscle & $29.85^{\mathrm{c}}$ & $31.14^{\mathrm{ab}}$ & $31.20^{\mathrm{ab}}$ & $32.48^{\mathrm{a}}$ & $30.59^{\mathrm{b}}$ & 0.38 \\
\% Wings & $13.46^{\mathrm{a}}$ & $11.60^{\mathrm{a}}$ & $12.20^{\mathrm{a}}$ & $13.06^{\mathrm{a}}$ & $12.30^{\mathrm{a}}$ & 0.29 \\
\% Backcut & $22.23^{\mathrm{a}}$ & $22.66^{\mathrm{a}}$ & $21.47^{\mathrm{a}}$ & $21.33^{\mathrm{a}}$ & $23.63^{\mathrm{a}}$ & 0.38 \\
\hline
\end{tabular}

${ }_{\mathrm{abc}}$ means within the same row with different superscripts are significantly different $(\mathrm{P}<0.05)$

There were no significant difference $(\mathrm{P}<0.05)$ on percentage wings and backcut of the finisher broilers group in all the diets. The finisher broiler on diet 4 (25\% SCYM) yielded the highest percent breast muscle of $32.4 \%$ followed by those on 15\% SCYM (diet 2) and 20\% SCYM (diet 3).
Significant differences also occurred in the yield of percent thigh. The finisher broilers on the control diet (diet 1) yield the highest percent thigh of $18.31 \%$ and the poorest were those on diet $2(15 \% \mathrm{SCYM})$.

\section{Internal organ weights}

The percentage internal organs weight of the experimental finisher are shown in (Table 7).

Table 7: Percentage Internal Organ weight of the Experimental Finisher Broiler

\begin{tabular}{lllllll}
\hline Parameters & Diet 1 & Diet 2 & Diet 3 & Diet & Diet 5 & SEM \\
\hline Av. Liveweight $(\mathrm{g})$ & $1850^{\mathrm{a}}$ & $1880^{\mathrm{ab}}$ & $2030^{\mathrm{a}}$ & $1780^{\mathrm{b}}$ & $1850^{\mathrm{ab}}$ & 36.88 \\
Dressed weight $(\mathrm{g})$ & $1280^{\mathrm{ab}}$ & $1300^{\mathrm{ab}}$ & $1500^{\mathrm{a}}$ & $1150^{\mathrm{b}}$ & $1200^{\mathrm{b}}$ & 53.54 \\
\% Dressed weight & $29.19^{\mathrm{ab}}$ & $69.15^{\mathrm{ab}}$ & $73.90^{\mathrm{a}}$ & $64.61^{\mathrm{b}}$ & $68.86^{\mathrm{ab}}$ & 1.52 \\
\% Liver & $1.70^{\mathrm{a}}$ & $1.65^{\mathrm{a}}$ & $1.98^{\mathrm{a}}$ & $1.91^{\mathrm{ab}}$ & $1.89^{\mathrm{a}}$ & 0.06 \\
\% Gizzard & $1.75^{\mathrm{b}}$ & $2.27^{\mathrm{a}}$ & $1.98^{\mathrm{b}}$ & $2.13^{\mathrm{a}}$ & $1.97^{\mathrm{c}}$ & 0.08 \\
And Heart & $0.43^{\mathrm{a}}$ & $0.44^{\mathrm{a}}$ & $0.42^{\mathrm{a}}$ & $0.44^{\mathrm{a}}$ & $0.51^{\mathrm{a}}$ & 0.01 \\
\% Spleen & $0.11^{\mathrm{a}}$ & $0.14^{\mathrm{a}}$ & $0.15^{\mathrm{a}}$ & $0.14^{\mathrm{a}}$ & $0.14^{\mathrm{a}}$ & 0.009 \\
\% Abdominal fat & $1.14^{\mathrm{b}}$ & $1.21^{\mathrm{ab}}$ & $1.87^{\mathrm{a}}$ & $1.24^{\mathrm{ab}}$ & $0.89^{\mathrm{a}}$ & 0.14 \\
\% Large intestine & $0.95^{\mathrm{a}}$ & $1.06^{\mathrm{a}}$ & $0.89^{\mathrm{a}}$ & $0.76^{\mathrm{a}}$ & $0.40^{\mathrm{a}}$ & 0.10 \\
\% Small intestine & $2.47^{\mathrm{a}}$ & $2.03^{\mathrm{a}}$ & $2.35^{\mathrm{a}}$ & $3.04^{\mathrm{a}}$ & $3.13^{\mathrm{a}}$ & 0.19 \\
\%Proventriculus & $0.42^{\mathrm{a}}$ & $0.48^{\mathrm{a}}$ & $0.47^{\mathrm{a}}$ & $0.55^{\mathrm{a}}$ & $0.55^{\mathrm{a}}$ & 0.02 \\
\% Kidney & $0.58^{\mathrm{a}}$ & $0.56^{\mathrm{a}}$ & $0.70^{\mathrm{a}}$ & $0.60^{\mathrm{a}}$ & $0.46^{\mathrm{a}}$ & .15 \\
\% Lungs & $0.51^{\mathrm{a}}$ & $0.68^{\mathrm{a}}$ & $0.66^{\mathrm{a}}$ & $0.77^{\mathrm{a}}$ & $0.71^{\mathrm{a}}$ & 0.04 \\
\hline
\end{tabular}

${ }^{\mathrm{abc}}$ means within the same row with different superscripts are significantly different $(\mathrm{P}<0.05)$

The weights of the organs (livers, gizzards, hearts, kidneys, spleen, large intestine, small intestines, proventriculus and lungs) of the birds in all the groups were not affected. The birds in diets $3,4,5$ and 1 accumulated more abdominal fat than others indicating higher efficiency of the birds in converting the carbohydrates of the diets into fat.

\section{Conclusion}

The study showed that 24 hour soaking duration of cocoyam tuber (Xanthosomasagittifolium) for processing broilers diets was not quite as effective method of processing cocoyam tuber meal for use in broilers as there were still traces of cyanide, tannins, phytic acid, saponins and oxalates in soaked cocoyam tuber meal as illustrated in this experiment but at a tolerable levels.

Finisher broilers on 20\% soaked cocoyam tubermeal performed better than those on maize based diet (control diet). Soaked cocoyam tubermeal could be used in the diet of finisher broilers up to $20 \%$ without affecting weight gain, feed intake and feed conversion ratio. 
References

A.O.A.C., 1995. Official methods of Analysis (16 ${ }^{\text {th }} \mathrm{Edn}$.), Association of official and Analytical chemist. Washington D.C.

Abdulrashid, M., Agwuwunobi, L. N., Akpa, G. N. and Adeyinka, F. D. 2006. The performance of broiler finisher on varying levels of taro cocoyam meal. Proc. Ann Conf., (pp. 3:285-287). Kano; Nig. Soc. Anim. Prod.

Adejinmi, O. O., Adejinmo, J. O., Adeleya, I. O. A. 2000 . Replacement value of fish meal with soldier fly larvae meal in broiler diets. Nigerian Poultry Science Journal (1): 52-60.

Agbede, J. O., Ajala, K., Aletor, V. A. 2002). Influence of Roxaenzyme of supplementation on the utilization of sorghum dust based diets for broiler chicks. Proc. $27^{\text {th }}$ Ann. Conf. NSAPAkure.

Agboola, S. D. 1987. Cocoyam storage and its potential for food sufficiency on future economic ecovery of Nigeria. In: Arena, O. B. et al. Proc. $1^{\text {st }}$ National Workshop on Cocoyam NRCRI, Umudike.

Agwunobi, L. N., Angwukam, P. O., Cora, O. O. and Isika, M. A. 2002. Studies on the use of colocasia esulenta (Taro cocoyam) in the diets of weaned pids. http: .

Ahamefule, F. O. and Odemelan, V. U. 2008. Effect of soaking duration on the proximate composition, gross energy, mineral content and some anti-nutritional properties of canavaliaplaglospermaseed. Proceedings of the $13^{\text {th }}$ Annual conference of the Animal Science Association of Nigeria (ASAN), $15^{\text {th }}-19^{\text {th }}$ sept., 2008. ABU, Zaria, Nigeria, pp:491-494.

Anyaegbu, B. C., Orgi, M. C., Ebuzor, C. A., Okwandu, P. and Adedoku, $O$. O. 2016. Replacement Value of Maize with different levels of $\mathrm{S}$ u n d r i e d C o c o y a m (Xanthosomasagittifolium) as energy source on finisher broilers performance. Proceedings of the $21^{\text {st }}$ Annual Conference of Animal Science Association of Nigeria 18$22^{\text {nd }}$ September, 2016, PortHarcourt.

Bello, A. J. N. 1976. Food and Nutrition in practice, Macmillian Education Education Ltd. London p. 32.

Eburuja, A. S. 2010. Chemical and Nutrition Evaluation of African yam bean as an alternative protein source in broiler diets. Ph.D Thesis, Michael Okpara University of Agriculture, Umudike.

Esonu, B. O. 2000. Effect of dietary cooked wild variegated cocoyam (Caladium hortulanum) on the performance of broiler chickens. Tropical Agric. 2000:22 (4): 269271.

F.A.O 1990. Roots, Tubers, Plantains and Bannanas in Human Nutrition. Rome: Food and Agric.Org. of the united Nations.

F.A.O 2004. Federal and Agricultural Organization Stat. Database; Food and Agriculture. Italy: Int'l Org. of the United Rome.

Food and Agricultural Organization FAO, 1982. Production Year book. Vol 37. Food and Agricultural Organization U.N.O Rome.

Gooding, E.G.B 1987. Crops and Product Digest 2 Root Crops, second Edition, London. Tropical Development and Research Institute 
XV 380PP.

Hamza, R. A., Tiamiyu, A. K. and Raji, A.

M. 2003. Effect of dietary inclusion of cocoa pod husk (KPA) on growth performance of West African Dwarf(WAD) goats. Proc. $28^{\text {th }}$ Annual Conference NSAP, Ibadan p. 271-3.

Ohaemenyi, C. E. 1993. A study of the corm of (Xanthosomasagittifolium (cocoyam) as a substitute for maize in the diet of young growing pigs. B.Sc. Thesis. Fed. Uni. of Tech. Owerri, Nigeria, 1993.

Okereke, C. O. and Ukachukwu, S. N. 2006. Effect of Dietary Inclusion of Composite Cassava Meal on Egg Production characteristics of laying hens. Student Thesis, Michael Okpara University of Agriculture, Umudike. Department of Non Ruminant Animal Nutrition and Biochemistry, PP 1-38.

Okon, B. I., Obi, M. B., Ayuk, A. A. 2007. Performance of quail (Cortunix japonica) fed graded levels of boiled sundried taro cocoyam (Colocasiaesculenta) as replacement to maize. Medwell outline Agric. J. 2007. 2(6): 654657.

Oluyemi, 1978. Certificate Agricultural Science. Longman Press Ltd.

Oluyemi, J. A. and. Roberts, P. A. 2000. Poultry production in the warm wet climates. Spectrum Book Limited Ibadan, Nigeria, pp: 103-108.

Onu, P. U., Madubuike, F. U., Uchewa, E. N., Otuma, M. O. and Asogwu, M. O. 2004. Effect of cooking on the nutritive value of wild cocoyam (caladium bicolor) in broiler starters ration. Proc. $9^{\text {th }}$ Annual Conf. Animal Sci. AGS of Nig.
(ASAN). Ebonyi State University Abakaliki.

Onunkwo, D. N., Anyaegbu, B. C., Odukwe, C. N., Amahiri, C. and Ogu, C. M. 2016. Replacement Value of Maize with Dried $\begin{array}{lllllll}\mathrm{C} & \mathrm{o} & \mathrm{c} & \mathrm{o} & \mathrm{y} & \mathrm{a} & \mathrm{m}\end{array}$ (Xanthosomasagittifolium) as Energy source on the performance of starter broilers. International Research Journal of Agricultural and Aquatic Sciences Vol.3 (1) Pp 124-128, January, 2016 ISSN 24112895. www.Sci-africpublishers.org.

Oyinmonyi, A.E., and Okeke, G.C. 2005. Carcass, Organ and Pathological characteristics of grower pigs fed cassava peel meal. J. agric. Food Environ. Ext., 1: 1-4.

Snedector, G. W. and Cochran, W. G. 1989. Statistical methods $8^{\text {th }}$ edition. Ames:lowa state university press.

Steel, R. D. G. and Torrie, J. H. 1980. Principal and procedures of statistics: A biometrical approach $2^{\text {nd }}$ edition, pp. 623.

Tewe, O. O. 1997. Sustainability and development paradigm from Nigeria's livestock Ind. Inaugural lecture delivered on behalf of faculty of Agriculture and Forestry, U.I.pg. 50.

Received: $10^{\text {th }}$ May, 2017 Accepted: $21^{\text {st }}$ August, 2017 